\title{
Influence of nitrogen source on the fermentation of fibre from barley straw and sugarbeet pulp by ruminal micro-organisms in vitro
}

\author{
M. J. Ranilla ${ }^{1}$, M. D. Carro ${ }^{1}$, S. López ${ }^{1}$, C. J. Newbold ${ }^{2}$ and R. J. Wallace ${ }^{2}$ \\ ${ }^{1}$ Departamento de Producción Animal I, Campus de Vegazana, Universidad de León, 24071 León, Spain \\ ${ }^{2}$ Rowett Research Institute, Bucksburn, Aberdeen AB21 9SB, UK \\ (Received 9 April 2001 - Revised 12 July 2001 - Accepted 25 August 2001)
}

\begin{abstract}
Incubations were carried out with a batch culture system to study the effects of different $\mathrm{N}$ sources on the fermentation by ruminal micro-organisms from Merino sheep of two fibre substrates derived from feedstuffs that differed in their fermentation rate. The substrates were neutral-detergent fibre (NDF) from barley straw and sugarbeet pulp. $\mathrm{N}$ sources were ammonia $\left(\mathrm{NH}_{4} \mathrm{Cl}\right)$ and peptides (Trypticase). Three treatments were made by replacing ammonia- $\mathrm{N}$ with peptide-N at levels of 0 (AMMO), 33 (PEPLOW) and $66 \%$ (PEPHIGH) of total N. There were no differences $(P>0.05)$ between treatments in NDF degradation for both the barley straw and the sugarbeet pulp. Peptides increased $(P<0 \cdot 05)$ total volatile fatty acids daily production for both substrates, with greater values $(P<0 \cdot 001)$ for PEPHIGH than for PEPLOW for the sugarbeet pulp. The presence of peptides also increased $(P<0 \cdot 05)$ microbial $\mathrm{N}$ synthesis compared with AMMO, with PEPHIGH supporting more growth $(P<0 \cdot 001)$ than PEPLOW when the sugarbeet pulp NDF was fermented. The presence of peptides increased $(P<0 \cdot 01)$ the amount of solidsassociated micro-organisms (SAM)-N for both the barley straw and the sugarbeet pulp fibres, values in the PEPHIGH treatment being higher $(P<0.001)$ than those in PEPLOW. The proportion of SAM-N in the total microbial $\mathrm{N}$ was not affected $(P>0.05)$ by the presence of peptides compared with the AMMO treatment, but values were greater for the PEPHIGH compared with the PEPLOW N source, reaching statistical significance $(P<0.05)$ only for the sugarbeet pulp. For liquid-associated micro-organisms, the AMMO treatment resulted in the greatest $(P<0.05)$ proportion of $\mathrm{N}$ derived from ammonia for both substrates, with a further decrease $(P<0.01)$ for the PEPHIGH treatment compared with the PEPLOW for the sugarbeet pulp, indicating preferential uptake of peptides when they were available. Microbial growth efficiency (g microbial N/kg NDF degraded) was not affected $(P>0.05)$ by $\mathrm{N}$ source. These results indicate that $\mathrm{N}$ forms other than ammonia are needed for maximal growth of fibredigesting ruminal micro-organisms.
\end{abstract}

Nitrogen: Rumen microbial protein synthesis: Batch cultures: Solids-associated microorganisms: liquid-associated micro-organisms

Despite sustained research effort carried out over the last 30 years to characterise the $\mathrm{N}$ metabolism of ruminal microorganisms, the $\mathrm{N}$ requirements for their optimum growth remain unclear. Based on pure culture studies, some nutritional models assume that bacteria fermenting structural carbohydrates use ammonia as the only $\mathrm{N}$ source, while bacteria that utilize non-structural carbohydrates have a fixed requirement for preformed amino acids (Russell et al. 1992). Recent work has questioned these assumptions, showing that in bacteria fermenting structural carbohydrates the proportion of microbial $\mathrm{N}$ derived from ammonia is not fixed and varies in accordance with the $\mathrm{N}$ source available (Atasoglu et al. 1998, 1999). Furthermore, it has been suggested that these bacteria can use peptides and amino acids as a $\mathrm{N}$ source when they are available both in pure culture (Ling \& Armstead, 1995; Wallace et al. 1999) and in mixed ruminal population studies (Carro et al. 1999; Carro \& Miller, 1999). Because cellulose is the most abundant component of plant cell walls, knowledge of the $\mathrm{N}$ requirements of bacteria that ferment structural carbohydrates is critical for the nutrition of ruminant animals fed diets based on forages. Furthermore, the efficient use of

\footnotetext{
Abbreviations: AMMO, treatment containing no peptide-NAN; LAM, liquid-associated micro-organisms; NAN, non-ammonia N; NDF, neutral-detergent fibre; PEPHIGH, high peptide treatment; PEPLOW, low peptide treatment; SAM, solids-associated micro-organisms; VFA, volatile fatty acids.

* Corresponding author: Dr M. J. Ranilla, fax +34 987 291311, email DP1MRG@UNILEON.ES
} 
either protein or non-protein $\mathrm{N}$ supplements in the practical feeding of ruminants depends on this information.

The results obtained in the different experiments conducted on this topic in recent years are contradictory. In some studies, providing non-ammonia N (NAN; amino acids, peptides, protein) in addition to ammonia has been shown to stimulate the growth of rumen bacteria (Cruz Soto et al. 1994; Chikunya et al. 1996; Carro \& Miller, 1999) and to enhance digestion of fibre (McAllan, 1991; Griswold et al. 1996; Carro \& Miller, 1999). No effect was observed in other studies (Fujimaki et al. 1989; Kernick, 1991). These contrasting results might be explained by differences in the composition of the diet, but also in the experimental procedures used to determine microbial protein synthesis.

A wide range of approaches has been used to quantify microbial protein in rumen contents and in digesta flowing at the duodenum, but all of them rely on the use of microbial markers. The use of microbial markers to study microbial $\mathrm{N}$ synthesis requires the knowledge of marker: $\mathrm{N}$ in an isolated microbial pellet. The liquid-associated micro-organisms (LAM) fraction is the most often harvested in order to establish marker: $\mathrm{N}$ for calculating the amount of microbial protein in digesta samples (Dewhurst et al. 2000), and this is an important point to be considered in interpreting the results of different experiments, as an ideal microbial pellet should be representative of both fractions. However, differences in the composition of LAM and solidsassociated micro-organisms (SAM), not only in their chemical composition but also in their marker: $N$, have been widely demonstrated (Merry \& McAllan, 1983; Martín-Orúe et al. 1998; Carro \& Miller, 1999). To our knowledge, in most of the experiments conducted to investigate the effects of NAN forms on rumen microbial growth, it has been assumed that marker: $N$ derived from LAM holds in the total population leaving the rumen.

The objective of the present study was to investigate the effects of peptides supplementation on microbial protein synthesis of LAM and SAM growing in vitro on neutral detergent fibre (NDF) as the only carbohydrate source.

\section{Materials and methods}

Substrates and experimental procedure

Two NDF (cell wall) sources were used in the present study: barley straw and sugarbeet pulp. In order to isolate forage cell walls, about $500 \mathrm{~g}$ of each forage was treated with neutral-detergent solution for $1 \mathrm{~h}$ at $105^{\circ} \mathrm{C}$ according to the method of Van Soest et al. (1991). The residue was then rinsed thoroughly at least fifteen times with hot distilled water and was dried at $50^{\circ} \mathrm{C}$ for $48 \mathrm{~h}$. The chemical composition of cell walls of both substrates is given in Table 1.

NDF samples were ground through a $1 \mathrm{~mm}$ screen and fermented in vitro with buffered rumen fluid. Four rumenfistulated Merino sheep fed a good-quality hay $(1200 \mathrm{~g} / \mathrm{d})$ were used as donors of rumen contents. Rumen contents of each sheep were mixed and homogenised in a blender at low speed, strained through two layers of nylon cloth $(40 \mu \mathrm{m}$ pore size) to remove large particles and mixed with a buffer solution $(1: 4, \mathrm{v} / \mathrm{v})$ at $39^{\circ} \mathrm{C}$ under continuous flushing with $\mathrm{CO}_{2}$. The buffer solution was prepared as described by Goering \& Van Soest (1970), with the exception that no Trypticase was added and ammonia bicarbonate was replaced by sodium bicarbonate. In order to stimulate the growth of cellulolytic bacteria, isobutyrate, isovalerate and valerate acids were added to the buffered rumen fluid to achieve concentrations of $0.3,0.9$ and $0.7 \mathrm{mM}$, respectively (Hume, 1970). In addition, $\mathrm{S}\left(\mathrm{Na}_{2} \mathrm{SO}_{3}\right)$ was added to the medium to achieve N:S of $10: 1$. A dose of ${ }^{15} \mathrm{~N}(98 \%$ enriched ${ }^{15} \mathrm{NH}_{4} \mathrm{Cl}$; Sigma-Aldrich Química, S.A., Spain) was added to the medium in a proportion of $1.335 \mathrm{mg}{ }^{15} \mathrm{~N} / 1$ medium to label the ammonia-N pool. Samples of $500 \mathrm{mg}$ of each NDF source were accurately weighed into $125 \mathrm{ml}$ serum bottles. Bottles were pre-warmed $\left(39^{\circ} \mathrm{C}\right)$ before the addition of $50 \mathrm{ml}$ buffered rumen fluid into each bottle under $\mathrm{CO}_{2}$ flushing. Bottles were sealed with rubber stoppers and aluminium caps and incubated at $39^{\circ} \mathrm{C}$.

Two forms of added $\mathrm{N}$ were evaluated: ammonia $\left(\mathrm{NH}_{4} \mathrm{Cl}\right)$ and peptides (Trypticase; BBL, Becton Dickinson, Cockeysville, MD). Three treatments were made by replacing ammonia-N with peptide- $\mathrm{N}$ at levels of 0 (AMMO), 33 (PEPLOW) and $66 \%$ (PEPHIGH) of total $\mathrm{N}$. Isonitrogenous solutions of the three forms were prepared and $1 \mathrm{ml}$ of the corresponding solution (containing $8 \mathrm{mg} \mathrm{N}$ ) was added to each bottle immediately before sealing. Four identical incubation runs were carried out, each of them with the mixed rumen fluid of the four sheep. In each incubation run, a total of twelve bottles was incubated for each substrate and $\mathrm{N}$ treatment.

\section{Fermentation kinetics from gas production curves}

Gas production was measured in two bottles at 3, 6, 9, 12, $16,19,24,30,36,48,60,72,96,120,144$ and $168 \mathrm{~h}$ using the pressure transducer technique (Theodorou et al. 1994). After $168 \mathrm{~h}$ of incubation, the fermentation was stopped by swirling the bottles in ice water, the bottles were opened and their contents were filtered through artificial fibre bags (\#F57, $50 \times 40 \mathrm{~mm}, 25 \pm 10 \mu \mathrm{m}$ pore size; ANKOM, 1998). The residue of incubation was washed with $50 \mathrm{ml}$ hot distilled water, dried at $50^{\circ} \mathrm{C}$ for $48 \mathrm{~h}$ and the $\mathrm{DM}$ apparent disappearance of substrate was calculated. The residues were then analysed for NDF content. In each incubation run, two blanks for each $\mathrm{N}$ treatment were included to correct the gas production values for gas release from endogenous substrates.

Table 1. Chemical composition ( $\mathrm{g} / \mathrm{kg}$ dry matter) of neutral-detergent fibre from barley straw and sugarbeet pulp

\begin{tabular}{lcccccc}
\hline & Acid-detergent fibre & Hemi-cellulose & Cellulose & Acid-detergent lignin & N & Acid-detergent insoluble N \\
\hline Barley straw & 662 & 338 & 625 & 37 & 7.9 & $0 \cdot 73$ \\
Sugarbeet pulp & 613 & 387 & 572 & 41 & $21 \cdot 7$ & 3.66 \\
\hline
\end{tabular}


Determination of microbial protein synthesis and fermentation parameters

The other ten bottles initially incubated for each substrate and $\mathrm{N}$ treatment were withdrawn from the incubator $24 \mathrm{~h}$ after inoculation and the fermentation was then stopped by swirling the bottles in ice. Of these, two bottles for each substrate and $\mathrm{N}$ source were used to measure volatile fatty acids (VFA) and NDF disappearance. These two bottles were opened and their content was filtered through the same artificial fibre bags described above. One sample $(1 \mathrm{ml})$ of the filtrate was added to $1 \mathrm{ml}$ of deproteinizing solution ( $10 \%$ of metaphosphoric acid and $0.06 \%$ crotonic acid; w/v) for VFA analysis. The residue of incubation was treated as explained above and analysed for NDF content.

Another four bottles for each NDF source and $\mathrm{N}$ treatment were used to obtain a sample of total digesta, to isolate total mixed microbial pellets and to measure ammonia in the supernatant fraction. Contents of the four bottles were mixed and homogenised in a blender at low speed for $1 \mathrm{~min}$. One portion (about $40 \mathrm{~g}$ ) was stored at $-20^{\circ} \mathrm{C}$ and freeze-dried to determine DM content. The residue, representative of total digesta, was analysed for NAN and ${ }^{15} \mathrm{~N}$ enrichment. Another $40 \mathrm{~g}$ of sample was centrifuged at $20000 \mathrm{~g}$ for $10 \mathrm{~min}$ and $20 \mathrm{ml}$ of the supernatant fraction was acidified with $20 \mathrm{ml}$ of $0.5 \mathrm{M} \mathrm{HCl}$ to reach a $\mathrm{pH}<3$ and preserved at $-20^{\circ} \mathrm{C}$ until ammonia- $\mathrm{N}$ and ${ }^{15} \mathrm{~N}$-enrichment determination. The rest of the pooled sample (about $120 \mathrm{~g}$ ) was incubated with $100 \mathrm{ml}$ of a saline solution of methylcellulose $(1 \mathrm{~g}$ methylcellulose $+9 \mathrm{~g} \mathrm{NaCl} / 1$ distilled water) at $39^{\circ} \mathrm{C}$ for $30 \mathrm{~min}$ to elute attached micro-organisms (Minato \& Suto, 1978) and frozen until the isolation of total mixed microbial pellets by differential centrifugation.

The rest of the bottles (four per $\mathrm{N}$ treatment and substrate) were used to obtain solid digesta, LAM and SAM pellets. The contents of the four bottles were mixed and homogenised in a blender at low speed for $1 \mathrm{~min}$ and then centrifuged at $500 \mathrm{~g}$ for $10 \mathrm{~min}$ at $4^{\circ} \mathrm{C}$. The supernatant fraction was removed, strained through a nylon cloth $(40 \mu \mathrm{m}$ pore size) and retained. Saline solution $(10 \mathrm{ml})$ was added to the residue, mixed well and the centrifugation was repeated. The supernatant fraction was removed, filtered and added to the one obtained previously. The final mixture of pooled supernatant fractions was frozen until isolation of LAM pellets. One portion of the solid residue (about $20 \mathrm{~g}$ ), considered representative of solid digesta, was stored at $-20^{\circ} \mathrm{C}$ and lyophilised to determine DM, NAN concentration and ${ }^{15} \mathrm{~N}$ enrichment. The rest of the residue was incubated with $60 \mathrm{ml}$ of a saline solution of methylcellulose $(1 \mathrm{~g}$ methylcellulose $+9 \mathrm{~g} \mathrm{NaCl} / 1$ distilled water) at $39^{\circ} \mathrm{C}$ for $30 \mathrm{~min}$ to elute attached micro-organisms (Minato \& Suto, 1978) and frozen until the isolation of SAM pellets.

TM, LAM and SAM were isolated by differential centrifugation following the procedure described by Carro \& Miller (1999). Microscopic examination of final bacterial pellets showed that they were essentially free from feed particles. Bacterial pellets were freeze-dried and analysed for $\mathrm{N}$ content and ${ }^{15} \mathrm{~N}$ enrichment.

\section{Analytical procedures}

$\mathrm{DM}$, ash and $\mathrm{N}$ were determined according to the Association of Official Analytical Chemists (1995). NDF was analysed as described by Van Soest et al. (1991). Aciddetergent fibre and lignin analyses were carried out according to the method of Goering \& Van Soest (1970). Acid-detergent insoluble $\mathrm{N}$ was determined by Kjeldahl analysis of the acid detergent fibre residues. Ammonia concentration was determined by a modified colorimetric method (Weatherburn, 1967). VFA were determined in centrifuged samples $(1 \mathrm{ml})$ by GC as previously described (Carro et al. 1999).

Samples of total and solid digesta (about $0.8 \mathrm{~g}$ ) were dampened with distilled water adjusted with $1 \mathrm{M} \mathrm{NaOH}$ to $\mathrm{pH}>10$ and dried at $90^{\circ} \mathrm{C}$ for $16 \mathrm{~h}$ to remove ammonia-N. The resulting residue was analysed for NAN and for ${ }^{15} \mathrm{~N}$ enrichment.

The preparation of samples for ${ }^{15} \mathrm{~N}$ analysis followed the procedure described by Carro \& Miller (1999). ${ }^{15} \mathrm{~N}$ analysis was performed by isotope ratio MS as described by Barrie \& Workman (1984).

\section{Calculations}

Gas production values were fitted with time to the exponential model:

$$
\text { gas }=A\left(1-\mathrm{e}^{(-c(t-l a g))}\right),
$$

where $A$ represents the asymptotic gas production, $c$ is the fractional degradation rate, lag is the initial delay in the onset of gas production and $t$ is the gas reading time. The parameters $A, c$ and lag were estimated by an iterative least squares procedure using the PROC NLIN of the Statistical Analysis Systems Institute (Statistical Analysis Systems, 1997). Effective degradability of the substrate (g/100 g NDF incubated) was estimated assuming a rumen particulate outflow of $0 \cdot 040 / \mathrm{h}$, according to the equation proposed by France et al. (2000). The average fermentation rate (ml gas/h) was defined as the average gas production rate between the start of the incubation and the time at which the cumulative gas production was half of its asymptotic value, and was calculated as:

$$
\text { rate }=A \times c /(2 \times(\ln 2+c \times \operatorname{lag})) .
$$

The proportion of total digesta NAN of microbial origin was estimated for each substrate and $\mathrm{N}$ treatment as ${ }^{15} \mathrm{~N}$ enrichment (atom \% excess) of the NAN portion of total digesta $/{ }^{15} \mathrm{~N}$ enrichment of total mixed microbial pellets. Daily microbial $\mathrm{N}$ production $(\mathrm{mg} / \mathrm{d})$ was estimated in each bottle by multiplying total NAN by the proportion attributed to the microbes. The proportion of solid digesta NAN of microbial origin was estimated as ${ }^{15} \mathrm{~N}$ enrichment of the NAN portion of the solid digesta $/{ }^{15} \mathrm{~N}$ enrichment of SAM. Daily SAM-N production was estimated by multiplying daily NAN production by the proportion attributed to SAM. The amount of LAM was calculated as TM-SAM. The proportion of bacterial $\mathrm{N}$ derived from ammonia- $\mathrm{N}$ was estimated as ${ }^{15} \mathrm{~N}$ enrichment of bacterial pellets / ${ }^{15} \mathrm{~N}$ enrichment of ammonia-N. For the calculations, two 
assumptions were made: (1), equal amounts of microbial plus residual feed $\mathrm{N}$ from the inoculum were dosed into all bottles for the same substrate at the beginning of the incubation; (2), by $24 \mathrm{~h}$, microbial NAN equilibrated to the same ${ }^{15} \mathrm{~N}$ enrichment.

\section{Statistical analysis}

Data were subjected to ANOVA. Treatment effects for fibre source, $\mathrm{N}$ treatment and fibre source $\times \mathrm{N}$ treatment were included in the model. Incubation run was included in the model as a blocking factor. As significant $(P<0.05)$ fibre source $\times \mathrm{N}$ treatment interactions were detected for most of the variables, $\mathrm{N}$ form effects were examined independently for each fibre source. The sums of squares attributed to $\mathrm{N}$ form were further partitioned to analyse the effects of peptide supplementation and of the level of peptide inclusion by orthogonal contrasts. The contrasts $\mathrm{C} 1$ and $\mathrm{C} 2$ were distributed as follows: $\mathrm{C} 1, \mathrm{AMMO} v$. peptides; $\mathrm{C} 2$, PEPLOW $v$. PEPHIGH. All analyses were conducted using the GLM procedure of the Statistical Analysis Systems (Statistical Analysis Systems, 1997).

\section{Results}

The effects of the form of $\mathrm{N}$ on gas production parameters and effective degradability are shown in Table 2. Asymptotic gas production $(A)$ tended to be higher $(P=0.052)$ in the presence of peptides when barley straw was incubated, whereas no effect of $\mathrm{N}$ source was detected for the sugarbeet pulp. The fractional rate of degradation $(c)$ was not affected $(P>0.05)$ by the presence of peptides for any substrate. Lag time was shorter $(P<0 \cdot 001)$ for both substrates when they were incubated with peptides compared with the AMMO treatment, with no further decrease at the higher peptides concentration. The supply of peptides increased $(P<0 \cdot 01)$ the average fermentation rate of sugarbeet pulp fibre, but no effect $(P>0.05)$ was observed for the barley straw. For both substrates, effective degradability was greater $(P<0 \cdot 05)$ when peptides were present compared with the AMMO treatment, and tended to be greater $(P<0 \cdot 10)$ with PEPHIGH compared with PEPLOW. Between both substrates, lag time was on average 5.5 to $5.9 \mathrm{~h}$ shorter for the sugarbeet pulp NDF than for the barley straw.

The effects of the form of $\mathrm{N}$ on the amount of NDF degraded, VFA and ammonia-N produced and NAN recovered in the culture bottles are shown in Table 3. There were no differences $(P>0.05)$ between treatments in the amount of NDF degraded at $24 \mathrm{~h}$ for both the barley straw and the sugarbeet pulp. Peptides increased $(P<0.05)$ total VFA daily production for both substrates, with greater values $(P<0.001)$ for PEPHIGH than for PEPLOW for the sugarbeet pulp. Peptides also increased $(P<0.05)$ the daily production of acetate, propionate, butyrate and isoacids compared with AMMO for both substrates. Whereas the concentration of peptides did not affect $(P>0.05)$ the production of the main VFA (acetate, propionate and butyrate) with the barley straw NDF, the higher concentration of peptides (PEPHIGH) increased $(P<0 \cdot 01)$ the production of acetate and propionate for the sugarbeet pulp fibre. The production of ammonia-N and total NAN recovered were not affected $(P>0.05)$ by $\mathrm{N}$ source.

The effects of $\mathrm{N}$ source on microbial $\mathrm{N}$ synthesis and its efficiency for the two NDF sources are shown in Table 4. For both substrates, the presence of peptides increased $(P<0 \cdot 05)$ total microbial $\mathrm{N}$ synthesis compared with AMMO, with PEPHIGH supporting more growth $(P<0 \cdot 10)$ than PEPLOW. The presence of peptides increased $(P<0.01)$ the amount of SAM-N for both the barley straw and the sugarbeet pulp fibres, values in PEPHIGH treatments being higher $(P<0.001)$ than those in PEPLOW ones. The proportion of SAM-N in the total bacteria $\mathrm{N}$ was not affected $(P>0.05)$ by the presence of peptides compared with the AMMO treatment, but values were greater for the PEPHIGH compared with the PEPLOW $\mathrm{N}$ source, reaching statistical significance $(P<0.05)$ only for the sugarbeet pulp. Microbial efficiency, expressed as $\mathrm{g}$ microbial N/kg NDF degraded, was not affected $(P>0.05)$ by $\mathrm{N}$ source, with similar values for both NDF substrates (mean value of 24.0 and $24.3 \mathrm{~g} / \mathrm{kg}$ for the barley straw and the sugarbeet pulp, respectively).

Table 2. Influence of different nitrogen sources on gas production parameters $(A, c$ and lag), average fermentation rate (AFR), and effective degradability (ED) of barley straw and sugarbeet pulp fibres incubated in batch cultures of mixed ruminal micro-organisms for $168 \mathrm{~h}^{*}$

(Mean values and standard errors of difference)

\begin{tabular}{|c|c|c|c|c|c|c|c|c|c|c|c|c|}
\hline \multirow[b]{2}{*}{ Variable } & \multicolumn{4}{|c|}{ Barley straw } & \multicolumn{2}{|c|}{$\begin{array}{c}\text { Statistical } \\
\text { significance of } \\
\text { contrast }(\mathrm{C}) \\
(P=)\end{array}$} & \multicolumn{4}{|c|}{ Sugarbeet pulp } & \multicolumn{2}{|c|}{$\begin{array}{c}\text { Statistical } \\
\text { significance of } \\
\text { contrast }(C) \\
(P=)\end{array}$} \\
\hline & AMMO & PEPLOW & PEPHIGH & SED & $\mathrm{C} 1 \dagger$ & $\mathrm{C} 2 \ddagger$ & AMMO & PEPLOW & PEPHIGH & SED & $\mathrm{C} 1 \dagger$ & $\mathrm{C} 2 \ddagger$ \\
\hline$A(\mathrm{ml})$ & $169 \cdot 1$ & $171 \cdot 1$ & $173 \cdot 3$ & 1.68 & 0.052 & NS & 229.8 & $230 \cdot 2$ & $227 \cdot 0$ & 1.82 & NS & NS \\
\hline$c(/ \mathrm{h})^{\prime}$ & 3.40 & 3.25 & 3.02 & 0.140 & NS & NS & 3.68 & 3.55 & 3.63 & 0.103 & NS & NS \\
\hline $\operatorname{lag}(\mathrm{h})$ & $15 \cdot 7$ & $13 \cdot 6$ & $13 \cdot 3$ & 0.37 & 0.001 & NS & 9.8 & 8.04 & $7 \cdot 8$ & 0.36 & 0.001 & NS \\
\hline AFR $(\mathrm{ml} \mathrm{h}) \S$ & 2.34 & 2.45 & 2.40 & 0.062 & NS & NS & 4.02 & $4 \cdot 18$ & $4 \cdot 21$ & 0.068 & 0.010 & NS \\
\hline ED $(\mathrm{g} / \mathrm{kg})$ & $18 \cdot 7$ & 19.9 & $19 \cdot 1$ & 0.43 & 0.040 & 0.095 & $27 \cdot 2$ & 29.6 & 30.4 & 0.40 & 0.001 & 0.060 \\
\hline
\end{tabular}

AMMO; PEPLOW; PEPHIGH, treatments whereby ammonia- $\mathrm{N}$ replaced by peptide- $\mathrm{N}$ at levels of 0,33 and $66 \%$ total $\mathrm{N}$ respectively.

${ }^{*}$ For details of procedures, see p. 718.

†Ammonia $v$. peptides.

$\ddagger$ Peptides low $v$. peptides high.

$\S$ Values for $500 \mathrm{mg}$ of substrate incubated. 
Table 3. Influence of different nitrogen sources on neutral detergent fibre (NDF) degradation, volatile fatty acids (VFA), ammonia and non-ammonia nitrogen (NAN) production from barley straw and sugarbeet pulp fibres by mixed ruminal micro-organisms in batch culture $(24 \mathrm{~h})^{*}$

(Mean values and standard errors of difference)

\begin{tabular}{|c|c|c|c|c|c|c|c|c|c|c|c|c|}
\hline \multirow[b]{2}{*}{ Variable } & \multicolumn{4}{|c|}{ Barley straw } & \multicolumn{2}{|c|}{$\begin{array}{c}\text { Statistical } \\
\text { significance of } \\
\text { contrast }(C)(P=)\end{array}$} & \multicolumn{4}{|c|}{ Sugarbeet pulp } & \multicolumn{2}{|c|}{$\begin{array}{c}\text { Statistical } \\
\text { significance of } \\
\text { contrast }(C)(P=)\end{array}$} \\
\hline & AMMO & PEPLOW & PEPHIGH & SED & $\mathrm{C} 1 \dagger$ & $\mathrm{C} 2 \ddagger$ & AMMO & PEPLOW & PEPHIGH & SED & $\mathrm{C} 1 \dagger$ & $\mathrm{C} 2 \ddagger$ \\
\hline $\begin{array}{l}\text { Degraded NDF }(\mathrm{mg}) \\
\text { VFA production }(\mu \mathrm{mol})\end{array}$ & 181 & 185 & 196 & 0.3 & NS & NS & 263 & 265 & 278 & $0 \cdot 2$ & NS & NS \\
\hline Acetate & 795 & 847 & 895 & $34 \cdot 2$ & 0.033 & NS & 1326 & 1418 & 1580 & 33.2 & 0.001 & 0.001 \\
\hline Propionate & 410 & 484 & 487 & $19 \cdot 9$ & 0.002 & NS & 601 & 645 & 700 & $15 \cdot 8$ & 0.001 & 0.008 \\
\hline Butyrate & 71 & 80 & 92 & $7 \cdot 6$ & 0.048 & NS & 154 & 179 & 211 & $14 \cdot 8$ & 0.012 & 0.061 \\
\hline Isoacids & 20 & 60 & 109 & $9 \cdot 4$ & 0.001 & 0.001 & 34 & 71 & 108 & 7.5 & 0.001 & 0.001 \\
\hline Total & 1297 & 1473 & 1584 & $60 \cdot 2$ & 0.002 & NS & 2116 & 2314 & 2600 & $56 \cdot 1$ & 0.001 & 0.001 \\
\hline Acetate:Propionate & 1.91 & 1.74 & 1.83 & 0.085 & NS & NS & $2 \cdot 19$ & $2 \cdot 20$ & $2 \cdot 24$ & 0.036 & NS & NS \\
\hline Ammonia N (mg) & $7 \cdot 59$ & $7 \cdot 58$ & $7 \cdot 33$ & 0.288 & NS & NS & $6 \cdot 61$ & 6.64 & $6 \cdot 61$ & 0.063 & NS & NS \\
\hline NAN (mg) & $9 \cdot 73$ & $10 \cdot 13$ & $10 \cdot 39$ & 0.724 & NS & NS & $17 \cdot 68$ & $18 \cdot 63$ & $18 \cdot 21$ & 0.546 & NS & NS \\
\hline
\end{tabular}

AMMO; PEPLOW; PEPHIGH, treatments whereby ammonia-N replaced by peptide- $\mathrm{N}$ at levels of 0,33 and $66 \%$ total $\mathrm{N}$ respectively.

*For details of procedures, see p. 718.

$\dagger$ Ammonia $v$. peptides.

$\ddagger$ Peptides low $v$. peptides high.

Table 4. Influence of different nitrogen sources on microbial nitrogen synthesis and efficiency of microbial synthesis (EMS) for barley straw and sugarbeet pulp fibres incubated in batch cultures of mixed ruminal micro-organisms $(24 \mathrm{~h})^{*}$

(Mean values and standard errors of difference)

\begin{tabular}{|c|c|c|c|c|c|c|c|c|c|c|c|c|}
\hline \multirow[b]{2}{*}{ Variable } & \multicolumn{4}{|c|}{ Barley straw } & \multicolumn{2}{|c|}{$\begin{array}{c}\text { Statistical } \\
\text { significance of } \\
\text { contrast }(C) \\
(P=)\end{array}$} & \multicolumn{4}{|c|}{ Sugarbeet pulp } & \multicolumn{2}{|c|}{$\begin{array}{c}\text { Statistical } \\
\text { significance of } \\
\text { contrast }(\mathrm{C}) \\
(P=)\end{array}$} \\
\hline & AMMO & PEPLOW & PEPHIGH & SED & $\mathrm{C} 1 \dagger$ & C2 $\ddagger$ & AMMO & PEPLOW & PEPHIGH & SED & $\mathrm{C} 1 \dagger$ & C2 $\ddagger$ \\
\hline \multicolumn{13}{|l|}{ Microbial $\mathrm{N}$ synthesis } \\
\hline Total $(\mathrm{mg})$ & 4.23 & 4.49 & $4 \cdot 84$ & 0.173 & 0.020 & 0.082 & $6 \cdot 26$ & $6 \cdot 50$ & $6 \cdot 81$ & 0.062 & 0.001 & 0.001 \\
\hline SAM (mg) & $2 \cdot 18$ & $2 \cdot 24$ & 2.59 & 0.069 & 0.003 & 0.001 & $3 \cdot 84$ & 3.91 & 4.42 & 0.089 & 0.003 & 0.001 \\
\hline SAM (\% of total) & $51 \cdot 3$ & $50 \cdot 1$ & $53 \cdot 6$ & 1.94 & NS & 0.088 & $61 \cdot 3$ & $60 \cdot 1$ & $65 \cdot 0$ & 1.74 & NS & 0.021 \\
\hline LAM (mg) & $2 \cdot 05$ & $2 \cdot 25$ & $2 \cdot 25$ & 0.153 & NS & NS & $2 \cdot 42$ & $2 \cdot 59$ & $2 \cdot 39$ & 0.131 & NS & NS \\
\hline \multicolumn{10}{|l|}{ Microbial $\mathrm{N}$ derived from ammonia-N (\%) } & 0.43 & NS & NS \\
\hline Total bacteria & $79 \cdot 4$ & $77 \cdot 2$ & $75 \cdot 0$ & $2 \cdot 57$ & NS & NS & 78.6 & $76 \cdot 0$ & $74 \cdot 8$ & $1 \cdot 14$ & 0.012 & NS \\
\hline SAM & $61 \cdot 4$ & $62 \cdot 6$ & $61 \cdot 6$ & 1.66 & NS & NS & $60 \cdot 5$ & $62 \cdot 1$ & $57 \cdot 7$ & 1.60 & NS & 0.026 \\
\hline LAM & $95 \cdot 1$ & 91.5 & $89 \cdot 6$ & $1 \cdot 17$ & 0.002 & NS & $90 \cdot 3$ & $89 \cdot 6$ & $84 \cdot 3$ & $1 \cdot 17$ & 0.011 & 0.002 \\
\hline
\end{tabular}

AMMO; PEPLOW; PEPHIGH, treatments whereby ammonia-N replaced by peptide-N at levels of 0,33 and $66 \%$ total $\mathrm{N}$ respectively; SAM, solids-associated micro-organisms; LAM, liquid-associated micro-organisms; NDF, neutral-detergent fibre.

*For details of procedures, see p. 718.

$\dagger$ Ammonia $v$. peptides.

$\ddagger$ Peptides low $v$. peptides high. 
There were differences among $\mathrm{N}$ sources in the proportion of bacterial $\mathrm{N}$ derived from ammonia. When total bacteria were considered, AMMO treatment resulted in the greatest $(P<0.05)$ value for the sugarbeet pulp, but there was no $\mathrm{N}$ source effect for the barley straw. For LAM, the AMMO treatment resulted in the greatest $(P<0.05)$ proportion of $\mathrm{N}$ derived from ammonia for both substrates, with a further decrease $(P<0.01)$ for the PEPHIGH treatment compared with the PEPLOW when the substrate was sugarbeet pulp NDF. There were no differences $(P>0.05)$ among AMMO and peptides treatments in the proportion of SAM-N derived from ammonia, but the proportion was smaller $(P<0 \cdot 05)$ for PEPHIGH compared with PEPLOW for the sugarbeet pulp.

\section{Discussion}

It is commonly assumed that bacteria fermenting structural carbohydrates do not incorporate peptides or amino acids, and thus all their $\mathrm{N}$ must come from ammonia (Bryant, 1973; Russell et al. 1992). However, recent in vitro work has shown that $\mathrm{N}$ forms other than ammonia are required for maximal fibre digestion (Griswold et al. 1996; Carro et al. 1999; Carro \& Miller, 1999). Furthermore, it has been suggested that the response of rumen micro-organisms to NAN is affected by the characteristics of the fermented substrate (Cruz Soto et al. 1994; Chikunya et al. 1996; Carro et al. 1999). Cruz Soto et al. (1994) proposed the hypothesis that there will be a point of inflexion in the microbial response to preformed amino acids. Below this point, peptides and amino acids will have no effect on microbial protein synthesis because the energy source will not permit more rapid growth, whereas above this point, growth is limited by the $\mathrm{N}$ rather than energy source if only ammonia is present, so that preformed amino acids can overcome this limitation. In the present experiment, two sources of fibre were incubated as substrates for cellulolytic bacteria. They were derived from barley straw, a slowly degraded fibrous feedstuff, and sugarbeet pulp, which is degraded more rapidly. The feedstuffs were extracted by procedures similar to those used for the preparation of NDF (Goering \& Van Soest, 1970). The aim was to see if the degradation rate of the fibres responded differently to preformed amino acids.

Cellulolytic bacteria require branched- and long-chain VFA for their biosynthesis of aliphatic amino acids, and a limitation of these compounds in ruminal fluid can inhibit their growth. A solution containing isobutyrate, isovalerate and valerate was added to the buffered rumen fluid, providing concentrations of those short-chain VFA in the medium (data not shown) higher than those which limit the growth of cellulolytic bacteria (Hume, 1970) for the three $\mathrm{N}$ treatments. On the other hand, the medium of Goering \& Van Soest (1970) is considered adequate to support optimal growth of ruminal bacteria. Thus, it could be assumed that in both treatments cellulolytic bacteria had adequate conditions for their growth (nutrient deficiencies other than the fibre substrate should not develop) and differences between treatments found in the present study should be due only to the $\mathrm{N}$ source.

The NDF from the two feedstuffs was fermented at similar rates, indicating that it is not the fibre itself which causes the different rates of breakdown of barley straw and sugarbeet pulp. Extraction to obtain the NDF must have removed the physical or chemical barriers which make barley straw more slowly degraded. Sugarbeet pulp NDF sustained higher microbial protein synthesis than barley straw with all $\mathrm{N}$ treatments. The response to the peptides supplementation was similar in both; thus, in terms of the hypothesis proposed by Cruz Soto et al. (1994) both the barley straw and the sugarbeet pulp fibres would possibly fall above the point of inflexion in the microbial response to preformed amino acids.

The replacement of ammonia by peptides increased the daily production of VFA for both sources of fibre. Similar results have been found by Carro \& Miller (1999) in semicontinuous fermenters fed an all-fibre basal diet, where the replacement of ammonia by amino acids, peptides and protein increased VFA daily production $1.4,1.3$ and 1.3 times, respectively. Other experiments carried out with continuous fermenters fed fibrous diets (Merry et al. 1990; Molina-Alcaide et al. 1996) also showed that the replacement of urea by non-urea $\mathrm{N}$ forms (amino acids, peptides, protein fishmeal) resulted in an increase in VFA production.

The lack of difference between $\mathrm{N}$ treatments in both the daily ammonia production and total NAN recovered (Table 3) would indicate an extensive degradation of peptides by the end of the incubation period. On the other hand, the contribution to the ammonia production from the NDF sources is likely to be the same for all treatments in view of the unchanged NDF digestion with $\mathrm{N}$ supplements.

The greater microbial $\mathrm{N}$ production for both peptides treatments compared with the AMMO treatment (Table 3) indicates that microbial growth of bacteria was stimulated by the presence of pre-formed amino acids. The decrease in lag time in the presence of peptides also suggests that they stimulate the initial activity of fibre degrading bacteria. In fact, the amount of SAM synthesised was increased by the presence of peptides for both the barley straw and the sugarbeet pulp NDF. This effect was more pronounced with PEPHIGH treatment, indicating that the stimulation of microbial growth by peptides could be dose-dependent (Atasoglu et al. 1998, 1999), at least to the higher concentration reached in this experiment. These results are consistent with the greater VFA values observed in the presence of peptides for both substrates, as increases in the VFA have been observed by including particulate microorganisms in the in vitro medium (Fay et al. 1980; Senshu et al. 1980). In contrast, Carro \& Miller (1999) found that the replacement of ammonia by NAN sources (amino acids, peptides and protein) did not increased the amount of SAM in semi-continuous fermenters. In that experiment the $\mathrm{N}$ sources were continuously infused into the fermenters and the basal diet was incubated in nylon bags. The authors argued that the NAN sources infused may have been degraded by the LAM so rapidly and completely that little actually reached the bacteria associated with the solid phase. However, the batch cultures used in the present experiment allow the instantaneous mixture of liquid and solid phases, and therefore, it is expected that peptides were readily available to SAM.

SAM may constitute a large proportion of the rumen 
microbial population (Craig et al. 1987). In our study, SAM represented about $50 \%$ of total microbial biomass when barley straw fibre was incubated and $62 \%$ for the sugarbeet pulp. These values are within the range of those found by Merry \& McAllan (1983) in steers receiving diets of equal proportions of roughage and concentrates and by Carro $\&$ Miller (1999) for semi-continuous fermenters fed a fibre basal diet. However, higher values have been reported in other in vivo experiments. Craig et al. (1987) reported a proportion of $70-80 \%$ of SAM in the rumen of cows fed a $65 \%$ alfalfa haylage diet, with values up to $90 \%$ in animals fed all-roughage diets (Faichney, 1980). The lower values in our batch culture system compared with some of those observed in vivo could be due to the different experimental conditions. Rumen DM content can vary with several factors, ranging from 10 to $25 \%$ (Czerkawski, 1986), whereas in our experiment DM at the end of the incubation represented only about $1 \cdot 5-2 \%$ of the total volume.

The lack of difference between AMMO and peptides treatments in the incorporation of ammonia- $\mathrm{N}$ by SAM seems to indicate that the supply of supplementary peptides did not decrease ammonia uptake. In contrast, the proportion of LAM derived from ammonia-N was greater for the AMMO treatment than for the peptides for both substrates, suggesting that LAM incorporated peptides when they were available. Similar results have been found by Carro \& Miller (1999) in semi-continuous fermenters fed a fibre basal diet. Bacteria fermenting non-structural carbohydrates are usually located in free suspension or loosely associated with feed particles and use either ammonia or peptides and amino acids as a $\mathrm{N}$ source (Russell et al. 1992). However, the fibre sources incubated in our study contained no non-structural carbohydrates and, therefore, the LAM must be loosely attached cellulolytic micro-organisms or micro-organisms fermenting secondary products released from NDF by the cellulolytic species.

Ammonia uptake by SAM was lower than that observed with LAM for both substrates, and this may be explained by the residual $\mathrm{N}$ in the fibre being used by SAM. Dixon \& Chanchai (2000) showed that the micro-organisms adherent to forages obtained much of their $\mathrm{N}$ substrates from the plant material rather that from the rumen ammonia pool even though ammonia concentrations were adequate for microbial activity. If there is sufficient residual $\mathrm{N}$ in the feed fibre, then the attached cellulolytic bacteria may have used this in preference to any other $\mathrm{N}$ source. In our experiment, the proportion of SAM derived from ammonia in the AMMO treatment indicates the uptake of $0.84 \mathrm{mg} \mathrm{N}$ for the barley straw and $1.51 \mathrm{mg} \mathrm{N}$ for the sugarbeet pulp that could only have come from the feed fibre.

In the experiment described in the present paper the extracted fibre from sugarbeet pulp and barley straw were degraded at similar rates, despite the different rates of degradation of the parent substrates. Fermentation of both fibres was slightly stimulated by preformed amino acids in terms of estimated effective degradability, total VFA production and microbial protein formation. Where these NDFs provided the only carbohydrate source in a batch culture system, the replacement of ammonia by peptides resulted in an increase in microbial growth, but mainly of SAM rather than LAM. The results confirm that $\mathrm{N}$ forms other than ammonia are needed for maximal growth of fibredigesting ruminal micro-organisms.

\section{Acknowledgements}

M. J. Ranilla gratefully acknowledges receipt of a research contract from the Ministerio de Educación y Cultura of Spain (Programa de Reincorporación de Doctores y Tecnólogos). The authors wish to acknowledge the financial support received from the Junta de Castilla y León of Spain (Projects LE29/98 and LE38/01) and the CICYT (Projects AGF98-0188 and Acción Integrada HB1997-0067). The Rowett Research Institute receives support from the Scottish Executive Rural Affairs Department.

\section{References}

ANKOM (1998) Procedures for Fibre and In Vitro Analysis. Accessed at www.ankom.com

Association of Official Analytical Chemists (1995) Official Methods of Analysis, 16th ed., Arlington, VA: Association of Official Analytical Chemists.

Atasoglu C, Valdés C, Newbold CJ \& Wallace RJ (1999) Influence of peptides and amino acids on fermentation rate and de novo synthesis of amino acids by mixed micro-organisms from the sheep rumen. British Journal of Nutrition 81, 307-314.

Atasoglu C, Valdés C, Walker ND, Newbold CJ \& Wallace RJ (1998) De novo synthesis of amino acids by the ruminal bacteria, Prevotella bryantii $\mathrm{B}_{1} 4$, Selenomonas ruminantium $\mathrm{HD} 4$, and Streptococcus bovis ES1. Applied and Enviromental Microbiology 64, 2836-2843.

Barrie S \& Workman CT (1984) An automated analytical system for nutritional investigations using N-15 tracers. Spectroscopy International Journal 3, 439-447.

Bryant MP (1973) Nutritional requirements of the predominant rumen cellulolytic bacteria. Federation Proceedings 32, 1809.

Carro MD, López S, Valdés C \& González JS (1999) Effect of nitrogen form (casein and urea) on the in vitro degradation of cell walls from six forages. Journal of Animal Physiology and Animal Nutrition 81, 212-222.

Carro MD \& Miller EL (1999) Effect of supplementing a fibre basal diet with different nitrogen forms on ruminal fermentation and microbial growth in an in vitro semicontinuous culture system (RUSITEC). British Journal of Nutrition 82, 149-157.

Chikunya S, Newbold CJ, Rode L, Chen XB \& Wallace RJ (1996) Influence of dietary rumen-degradable protein on bacterial growth in the rumen of sheep receiving different energy sources. Animal Feed Science and Technology 63, 333-340.

Craig WM, Broderick GA \& Ricker DB (1987) Quantitation of microorganisms associated with the particulate phase of ruminal ingesta. Journal of Nutrition 117, 56-62.

Cruz Soto R, Muhammed SA, Newbold CJ, Stewart CS \& Wallace RJ (1994) Influence of peptides, amino acids and urea on microbial activity in the rumen of sheep receiving grass hay and on the growth of rumen bacteria in vitro. Animal Feed Science and Technology 49, 151-161.

Czerkawski JW (1986) An Introduction to Rumen Studies, Oxford: Pergamon Press.

Dewhurst RJ, Davies DR \& Merry RJ (2000) Microbial protein supply from rumen. Animal Feed Science and Technology 85, $1-21$.

Dixon RM \& Chanchai S (2000) Colonization and source of N substrates used by microorganisms digesting forages incubated in synthetic fibre bags in the rumen. Animal Feed Science and Technology 83, 261-272. 
Faichney GJ (1980) Measurements in sheep of the quantity and composition of rumen digesta and the fractional outflow rates of digesta constituents. Australian Journal of Agricultural Research 31, 1129-1137.

Fay JF, Cheng KJ, Hanna MR, Howarth RE \& Costerton JW (1980) In vitro digestion of bloat-safe and bloat-causing legumes by rumen microorganisms: gas and foam production. Journal of Dairy Science 63, 1273-1281.

France J, Dijkstra J, Dhanoa MS, López S \& Bannink A (2000) Estimating the extent of degradation of ruminal feeds from a description of their gas production profiles observed in vitro: a derivation of models and other mathematical considerations. British Journal of Nutrition 83, 143-150.

Fujimaki T, Kobayashi M, Wakita M \& Hoshino S (1989) Influence of amino acid supplement on cellulolysis and microbial yield in sheep rumen. Journal of Animal Physiology and Animal Nutrition 62, 119-124.

Goering MK \& Van Soest PJ (1970) Forage Fiber Analysis (Apparatus, Reagents, Procedures and Some Applications). Agricultural Handbook, no. 379. Washington, DC: Agricultural Research Services, USDA.

Griswold KE, Hoover WH, Miller TK \& Thayne WV (1996) Effect of form of nitrogen on growth of ruminal microbes in continuous culture. Journal of Animal Science 74, 483-491.

Hume ID (1970) Synthesis of microbial protein in the rumen. II. A response to higher volatile fatty acids. Australian Journal of Agricultural Research 21, 297-304.

Kernick BL (1991) The effect of form of nitrogen on the efficiency of protein synthesis by rumen bacteria in continuous culture. $\mathrm{PhD}$ Thesis, University of Natal.

Ling JR \& Armstead IP (1995) The in vivo uptake and metabolism of peptides and amino acids by five species of rumen bacteria. Journal of Applied Microbiology 78, 116-124.

McAllan AB (1991) Carbohydrate and nitrogen metabolism in the forestomachs of steers given untreated or ammonia treated barley straw diets supplemented with urea or urea plus fishmeal. Animal Feed Science and Technology 33, 195-208.

Martín-Orúe SM, Balcells J, Zakraoui F \& Castrillo C (1998) Quantification and chemical composition of mixed bacteria harvested from solid fractions of rumen digesta: effect of detachment procedure. Animal Feed Science and Technology 71, 269-282.
Merry RJ \& McAllan AB (1983) A comparison of the chemical composition of mixed bacteria harvested from the liquid and solid fractions of rumen digesta. British Journal of Nutrition 50, 701-709.

Merry RJ, McAllan AB \& Smith RH (1990) In vitro continuous culture studies on the effect of nitrogen source on rumen microbial growth and fibre digestion. Animal Feed Science and Technology 31, 55-64.

Minato H \& Suto T (1978) Technique for fractionation of bacteria in rumen microbial ecosystem. II. Attachment of bacteria isolated from bovine rumen to cellulose powder in vitro and elution of bacteria attached therefrom. Journal of General and Applied Microbiology 24, 1-16.

Molina-Alcaide E, Weisbjerg MR \& Hvelplund T (1996) Degradation characteristics of shrubs and the effect of supplementation with urea or protein on microbial production using a continuous-culture system. Journal of Animal Physiology and Animal Nutrition 75, 121-132.

Russell JB, O'Connor JD, Fox DG, Van Soest PJ \& Sniffen CJ (1992) A net carbohydrate and protein system for evaluating cattle diets: I. Ruminal fermentation. Journal of Animal Science 70, 3551-3561.

Senshu T, Nakamura K, Sawa A, Miura H \& Matsumoto T (1980) Inoculum for in vitro rumen fermentation and composition of volatile fatty acids. Journal of Dairy Science 63, 305-312.

Statistical Analysis Systems (1997) SAS User's Guide, Statistics, Cary, NC: SAS Institute Inc.

Theodorou MK, Williams BA, Dhanoa MS, McAllan AB \& France J (1994) A simple gas production method using a pressure transducer to determine the fermentation kinetics of ruminant feeds. Animal Feed Science and Technology 48, 185-197.

Van Soest PJ, Robertson JB \& Lewis BA (1991) Methods for dietary fiber, neutral detergent fiber, and nonstarch polysaccharides in relation to animal nutrition. Journal of Dairy Science 71, 3583-3597.

Wallace RJ, Atasoglu C \& Newbold CJ (1999) Role of peptides in rumen microbial metabolism. Asian-Australasian Journal of Animal Science 12, 139-147.

Weatherburn MW (1967) Phenol-hypochlorite reaction for determination of ammonia. Analytical Chemistry 39, 971-974. 